\title{
Whose voices matter? Adults with learning difficulties and the emancipatory potential of numeracy practices
}

\author{
Silke Schreiber-Barsch ${ }^{1} \cdot$ Wiebke Curdt $^{1} \cdot$ Hanna Gundlach ${ }^{1}$
}

Accepted: 16 January 2020 / Published online: 27 January 2020

(c) The Author(s) 2020

\begin{abstract}
In this paper we explore the numeracy practices of adults with learning difficulties (also termed intellectual disabilities). For this purpose, the perspectives of a social practice view on numeracy practices and the concepts of disability and vulnerability were adopted. We argue that little research attention has been paid so far to this social group from an adult's perspective, using the benefits of a small-scale qualitative approach and principles of participatory research. It is for this reason that in the paper we present selected insights gained in an exploratory qualitative study in which we conducted shadowing and interviews with adults with learning difficulties as well as focus groups with professionals. The unit of analysis is social practices, which shifts the attention from behavioural or cognitive facets of individuals towards the ways of acting out numeracy in everyday contexts. In our conclusion, we argue for a resource-oriented perspective on numeracy learning, thus recognising the voices of all adult learners, and for emphasising the emancipatory potential of acting out numeracy, which help enable rather than disable learners.
\end{abstract}

Keywords Numeracy practices · Disability · Intellectual disability · Participatory research · Grounded theory methodology $\cdot$ Vulnerability

\section{Introduction}

An extensive body of educational research, global testing regimes like the Programme for the International Assessment of Adult Competencies (PIAAC), and policy agendas such as the United Nation's (UN) Sustainable Development Goals (SDGs) (Target 4.6) give credit to the relevance of numeracy. The relevance is derived from its "recognized role in contributing to the empowerment, effective functioning, economic status, and well being of citizens and their communities", echoing Gal (Gal 2000, p. ix; see also Gal et al. 2020). On this basis, we elaborate on numeracy in relation to the age group of adults and target their numeracy practices.

Silke Schreiber-Barsch

Silke.Schreiber-Barsch@uni-hamburg.de

Wiebke Curdt

Wiebke.Curdt@uni-hamburg.de

Hanna Gundlach

Hanna.Gundlach@uni-hamburg.de

1 Unit of Lifelong Learning (LLL), Faculty of Education, University of Hamburg, Alsterterrasse 1, 20354 Hamburg, Germany
The term 'adults' refers here to persons who are considered to be adults at the age of 16 and older (as done, for example, in the PIAAC survey).

We first began exploring their relation to numeracy by following the definition proposed by Geiger et al. (2015). The authors concluded that the term 'numeracy' usually identifies "the knowledge and capabilities required to accommodate the mathematical demands of private and public life, and to participate in society as informed, reflective, and contributing citizens" (p. 531). This rich interpretation of numeracy guided our rationale for this study. The interpretation accounts for both the mastery of school mathematics and "the capability to: make sense of non-mathematical contexts through a mathematical lens; exercise critical judgement; and explore and bring to resolution real world problems" (p. 531).

Secondly, focussing on numeracy practices, we aligned our investigations with the scholarly work on individual ways of acting out numeracy and the subjective meanings ascribed to doing this in a particular socio-cultural context (see, e.g., Yasukawa et al. 2018b). We were interested in how this engagement is integral to participating in community and society in the multiple ways that Gal (2000) listed 
above, as well as how it contributes to adults leading life as independently, actively and self-determinately as is possible — and desirable. Knowledge about this numeracy participation nexus is seen to be highly relevant with regard to vulnerable social groups; in this paper, adults with learning difficulties (also termed intellectual disabilities [ID]). These adults are commonly deemed to be vulnerable because they are considered to have very low numeracy proficiencyconsequently, they are seen as having fewer opportunities to participate in society (see, e.g., Prendergast et al. 2017, pp. 170-171; Spassiani and Friedman 2014). Vulnerability in this sense arises from acting out numeracy under the conditions of an impairment. Thus, whilst disability is not a pedagogical subject itself, it becomes so due to its influence on an individual's reservoir of numeracy-related abilities and his or her development of numeracy skills. Therefore, ensuring that persons with disabilities are entitled and have access to equitable learning opportunities and choices in order to acquire and develop abilities and skills relevant to numeracy, is a prerequisite of realising a "numerate adult citizenship" (Faragher 2019, p. 206; Niss 1994, p. 376).

However, although there is a growing body of scholarship on numeracy and disability, we found that little attention has been paid to the numeracy practices of this social group from an adult's perspective, and few studies have made use of a small-scale qualitative research approach. It is for this reason that we conducted an exploratory qualitative study on the numeracy practices of adults with learning difficulties. ${ }^{1}$ In this paper, we present selected insights derived from the collected data. We begin by investigating theoretical and empirical contributions that outline the specificities of our focus (Sect. 2). References to the German context are included in Sect. 2 in order to explain the setting in this country, and the interpretations of the selected data in Sect. 3. With the latter we aim to give readers insight into the methodological principles that informed our research design. In our conclusion, we discuss the data's contribution to the debate on whose voices matter in numeracy research and educational practice, and to the question regarding how the ability to act out numeracy incorporates an emancipatory potential (see Sects. 4 and 5).

\footnotetext{
${ }_{1}$ Numeracy practices of adults with learning difficulties (NumPuD). Part of the Hamburg Numeracy Project, funded by Landesforschungsförderung Hamburg (2017-2020) (LFF-FV 52).
}

\section{Encountering perspectives of the numeracy practices of adults and the concepts of disability and vulnerability}

\subsection{Reviewing the research}

In anthropological terms, disability is part of the conditio humana: "all of us either are or will become disabled to one degree or another during the course of our lives" (UN 2015). This might include physical, mental, intellectual or sensory issues, whether singular or in combination. Likewise, we are all deemed as being vulnerable due to being human (Zirfas 2017). Nonetheless, individuals and social groups differ in their level of exposure to risks-thus, they differ in their vulnerabilities (Burghardt et al. 2017).

In order to understand how such vulnerabilities affect acting out numeracy, we begin by referring to existing scholarly work on the interlinkage of numeracy and disability within the context of (adult) education. The body of scholarship differs, firstly, in the targeted age of participants in the research. For example, Fritz et al. (2019) prioritised the age group of small children and students, as did Browder et al. (2008), Faragher (2019), Peng et al. (2018) and Tan et al. (2019) in their work. That being said, these studies are still relevant to our understanding of numeracy learning as a "lifelong and lifewide" process (Jackson et al. 2018, p. 244), because they elicit the foundations that are meant to be laid via a formal schooling system (see Sect. 3.2). Lifelong learning necessarily complements, consolidates and broadens this educational foundation according to changing needs, interests and tasks throughout our lifespan.

Secondly, studies vary in the type of impairment they target. They refer to learning disabilities (Vogel and Reder 1998), mathematical learning difficulties (Fritz et al. 2019; Peng et al. 2018; Scherer et al. 2016), or intellectual disabilities (Tan et al. 2019; Prendergast et al. 2017). Nonetheless, the terminological and conceptual boundaries between these types are not always clear-cut (see Sect. 2.2). However, numeracy studies on not just adults but particularly on adults with intellectual disabilities are clearly outnumbered. This imbalance exists even within disability studies (Di Lorito et al. 2018, p. 669; Stalker 2014, p. 125) or large-scale surveys: The US PIAAC background questionnaire (BQ) collected data on disability status but not on intellectual disability (Patterson and Paulson 2015, p. 11). The 2012 German PIAAC survey (GESIS 2012) left out persons living in institutional settings, which greatly reduced the probability that adults with learning difficulties would be included in the sample. This was confirmed by its findings: A descriptive analysis of the PIAAC Scientific Use File revealed that out of the total number of interviewees $(n=5379)$, 
only 20 persons $(0.4 \%)$ opted for 'another school-leaving certificate', which would include certificates like the special-needs school-leaving certificate (B_Q01aDE1 [ALL]) (GESIS 2012, p. 7).We agree therefore with Stepanek Lockhart (2018) that "only what is measured gets counted" (p. 228) - thus, the abilities of the adults under scrutiny remain largely unexamined.

Thirdly, the scholarly body differs in terms of the epistemological foundations adopted. Tan et al.'s (2019) stocktaking of US research papers (2006-2017) on mathematics school education and ID examined the distribution of various conceptual and methodological approaches and the resulting knowledge paradigms. The authors documented the predominance of cognitive testing and behaviourism rationales that favoured medical models of disability and deficitoriented perspectives (see also Magne 2003, and Sect. 2.2). Such medical models interpret disability as a primarily individual and biological factor to be 'fixed' by medical or other treatments (Barnes 2014). This model dominated the thinking in many countries up until the 1960s, and it continues to inform deficit-oriented perspectives. For example, the German core curriculum for adult basic education in mathematics (DVV 2017) describes the participants in such courses as those with a mathematical learning biography that must be understood as a "biography of failure" (Meyerhöfer 2017, p. 5; authors' translation) - that is to be 'fixed' by adult education. In contrast, Tan et al. (2019) were interested in the "principles and practices in examining ways in which students with intellectual disabilities are honored as mathematics doers and thinkers" (p. 1). We call this a resourceoriented perspective on numeracy learning.

\subsection{Adults with learning difficulties and the dilemmas of labelling}

Studies have consistently shown that labelling procedures for what is considered as a disability, its categorisation and policy conceptualisation vary substantially [WHO-World Health Organization (2007), pp. 17-24; Watson et al. 2014; Porter and Lacey 2005, pp. 1-16]. These controversies are also addressed in the educational numeracy debate with regard to disability (e.g., Magne 2003; Scherer et al. 2016; Faragher 2019; Tan et al. 2019). Concerning this controversial field, we recognise the multi-faceted nature of disability and have chosen to follow the cultural model of disability. This model is advocated in disability studies (Goodley 2017; Waldschmidt 2019) and informed, for example, by the theoretical approach of ableism (Campbell 2009). The model emphasises the intersections between biological, social, cultural and psychological aspects as well as attitudes, norms and personal perceptions; it also explicitly pays attention to power structures.
In particular, we follow understandings of disability that debate its impact on participation, such as the UN Convention on the Rights of Persons with Disabilities (hereafter, UN Convention): "Persons with disabilities include those who have long-term physical, mental, intellectual or sensory impairments which in interaction with various barriers may hinder their full and effective participation in society on an equal basis with others" (UN 2006, p. 3). The International Classification of Functioning, Disability and Health (ICF) (WHO 2001) pursued the same logic by seeing disability as a dynamic interaction between a person's health condition and contextual factors (p. 4). In addressing the subcomponent of intellectual disability, the UN Convention and the ICF have argued against using an intelligence quotient (IQ) score. Such a score has been seen as necessary to grade the level of a person's intellectual functioning (see e.g., AAIDD 2019). However, terminologies and conceptualisations differ substantially also in this regard (Neuhäuser and Steinhausen 2013, pp. 16-21; WHO 2007, p. 17). In Germany, the equivalent term for intellectual disability (geistige Behinderung) has been used for persons assigned an IQ score of 55 and below since 1973 (Neuhäuser and Steinhausen 2013, p. 18). Internationally, and still valid today in the United States (US), a score of 70 or below indicates a so-called 'intellectual disability', thus incorporating persons who would be diagnosed with a learning disability according to Germany's standards.

Therefore, a label of 'intellectual disability' cannot be assigned solely by referring to measurable limitations in a diagnostic sense, nor can it be given based on an impairment. The latter might involve, in the case of ID, a "significant impairment in the conceptual (e.g., language, reasoning, memory), social (e.g., empathy, communication) and practical (e.g., personal care, money management) domains of the individual" (Di Lorito et al. 2018, p. 669). Instead, it must always be seen as an outcome of a suspected or proven 'clash' between a person's (perceived) abilities and the context-contingent expectations of certain degrees of functioning that are considered to be basic within that environment (Neuhäuser and Steinhausen 2013, p. 16; Weisser 2018; Faragher 2019; Tan et al. 2019).

Accordingly, Weisser (2018) spoke of disability as a phenomenon that raised an ability conflict through a person performing a social practice in a particular environment and its expectations of functioning (p. 99). The dilemma is that this conflict is labelled by standards that mostly attribute it to a deficit. Referencing sociological stigma theory, in 1967, US anthropologist Edgerton (1967) emphasised that "no other stigma is as basic as mental retardation in the sense that a person so labeled is thought to be so completely lacking in basic competence" (p. 207). This explains why major self-advocacy groups comprising people with so-called ID, like People First, founded in the US in 1974, rejected the 
devaluing and stigmatising label of mentally retarded (Di Lorito et al. 2018, p. 669; Walmsley and Johnson 2016; Higgins 2014). While the US replaced mentally retarded with intellectually disabled in 2010 - a major step in destigmatisation efforts (Higgins 2014) - these terminologies are still contested. People First in the US, in the United Kingdom (UK) (Chapman 2013, p. 44; Porter and Lacey 2005, p. 1) and the equivalent terminology used by People First Germany proposed the notation adults with learning difficulties (Menschen mit Lernschwierigkeiten). Therefore, in accordance with our research design - which is based on the cultural model of disability, disability studies and principles of participatory research that explicitly value a resource-, not deficit-oriented, perspective of disability —we have adopted use of the term learning difficulties to refer to those abilities that others describe as intellectual disabilities.

\subsection{Vulnerabilities and numeracy across the arenas of everyday life}

Vulnerabilities and numeracy-related abilities are fundamentally related to and influenced by both a person's innate reservoir and his or her concrete living situation in a particular socio-cultural context (and, e.g., its labelling mechanisms) at a certain geographical place and specific moment in time.

Concerning this reservoir, we suggest that all adults are understood as having an innate ability to engage (more or less) in numeracy-related learning activities and practices. Researchers have largely agreed that abilities mirror a basic blend of a human's reservoir of physical and mental aptitudes (e.g., Straka and Macke 2009, p. 15). These aptitudes provide a substantial, yet extendible, foundation because abilities mirror an individual's combination of knowledge and of cognitive, corporal and motivational-emotional dispositions to do what he or she intends to do (or not to do). The gradually more future-oriented meaning of a yet-unrealised potential is often termed capability (see Geiger et al. 2015 in Sect. 1). The concept of skills differs from these notions by drawing on learnt or acquired routinized abilities and proficiencies in reference to performing a particular task. Accordingly, the assessment of an ability's quality or degree always refers to standards set by a socio-culturally constructed reference framework: for example, a numeracy skills score (OECD 2016, p. 24).

Moreover, all the factors comprising a living situation "may influence adults' ability to act in a numerate way" (Gal et al. 2009, p. 31), a fact which the PIAAC survey recognises by collecting data on the frequency of numerate behaviour. Each individual's living situation provides the scope of action, which that person exploits when engaging in practices under the conditions of an impairment. Here, we have chosen to align with a social practice perspective on numeracy (Yasukawa et al. 2018b; Street et al. 2008; Street
1984). Research through this lens "focuses on what people $d o$ with numeracy through social interactions in particular contexts, rather than on people's performance of mathematical skills in isolation of context" (Yasukawa et al. 2018a, p. 13; emphasis in original). According to Reckwitz (2003), a practice is not just a behaviour or an intangible form of communication. Rather, it incorporates a more or less visible pattern of how particular things get done, which involves a person's body (enactment of the practice), tacit and explicit forms of embodied knowledge, capabilities and meanings and material resources (artifacts). Events, or externally recognisable parts of larger social practices, are visible to others (Street et al. 2008); however, the only way comprehensively to understand the meaning of an event is to reveal how it is embedded in social practices. In turn, the visibility allows us to reconstruct analytically the overall modality of social practices, even though these modalities might be invisible or disguised to the persons enacting them (e.g., Jackson et al. 2018, pp. 243-244; Yasukawa et al. 2018a, p. 225). These studies clearly underline the historically, socially and personally situated nature of practices (Jackson et al. 2018, p. 246). Therefore, practices are not only context-contingent and person-related, but they are also subject to change as part of learning processes.

Examining numeracy practices points to numeracyrelated activities across the arenas of everyday life. With regard to the adults under scrutiny, these arenas can be distinguished into four main contexts of everyday life (corresponding to OECD 2016, p. 24; BMAS 2016, pp. 20-22, 154): (1) work; (2) education and training; (3) living (including financial and material resources; type of living [residential care, assisted, with parents, on their own, with partners]; taking care of basic needs [e.g. shopping for food]); and (4) free time (e.g., pursuing a personal life and interests, health and well-being, taking part in society and community). The intersectional relations between these four contexts mutually aggravate a person's exposure to vulnerabilities. This is confirmed by empirical data collected in Germany, though the results are not clear-cut (BMAS-Bundesministerium für Arbeit und Soziales 2016, p. 533). In 2013, a total of 299,000 persons were labelled as having an ID or a learning disability, with no distinction between these two types (p. 46). In contrast to other types of impairment, the majority (59\%) of people in this category were significantly younger (aged below 45 years) (p. 47).

Of all persons living in residential care-which offers few opportunities for self-determined living-64\% are labelled as having an ID (BMAS-Bundesministerium für Arbeit und Soziales 2016, p. 251, 282). Persons living in residential care are also identified as being much more vulnerable in their exposure to violence and to severe restrictions of self-determination (p. 388). Concerning free time, BMAS defines this as "the time, which one has freely at one's own 
disposal and which can be spent in a self-determined way" (p. 352; authors' translation). Persons with and without disabilities both express the same need to spend their free time in a self-determined way; however, persons with disabilities encounter far more barriers to doing this (e.g., limited financial resources, physical barriers, health limitations) and their participation is considerably lower (pp. 356-371). Regarding education and training, persons with disabilities undergo vocational training and/or pursue (qualified) employment in the primary labour market far less often. Instead, the majority of people with disabilities-particularly those who are labelled as having an ID—work at sheltered workshops (pp. 119-124, 222, 196). Sheltered workshops allow for participation in the context of work; however, they are not intended to enable transitions to vocational training or (sheltered) jobs in the primary labour market, nor are they considered to be regular employment. Hence, they are decoupled from legal regulations such as minimum wage or pension funds, which greatly influences the financial resources of the people employed there (pp. 163-164).

\section{Numeracy practices of adults with learning difficulties: a glance at the data}

The limited extant knowledge regarding the numeracy practices of adults with learning difficulties called for an exploratory study following a qualitative research paradigm (Creswell 2003, pp. 198-199). Ethnographic-orientated studies of in situ numeracy practices (Yasukawa et al. 2018a, p. 14) allow researchers to derive insights that are not or cannot yet be satisfactorily examined by large-scale assessment surveys (Jackson et al. 2018, p. 248; Evans 2019, p. 68). Such bottom-up approaches (Evans et al. 2017, p. 18) do not seek to provide generalisations, but an in-depth understanding of subjective sense-making processes as they unfold in everyday contexts. The present research was conducted in Hamburg, Germany (though it is not a temporally and spatially intrinsically bounded case study; Merriam and Tisdell 2016, p. 39).

The unit of analysis used in this work was social practices (not behavioural or cognitive facets of individuals to be assessed). With this focus, we intended to shift the attention "towards a consideration of how things get done and how social practices are shaped" (Williams et al. 2018, p. 170). Our research was guided by a threefold set of questions:

1. In which ways do adults with learning difficulties engage in numeracy practises in their everyday contexts?

2. To what extent are their numeracy-related abilities mirrored in these practices?
3. What are the meanings these adults ascribe to their practices?

We first examined ways of acting out numeracy by conducting in situ observations of numeracy-related events and situations (Street et al. 2008) across the four identified arenas of everyday life in order to encompass numeracy-related "real world problems" (Geiger et al. 2015, p. 531). Second, we identified the presence of numeracy-related abilities within these practices in order better to systematise these observations (in terms of numeracy), and to associate our findings with standard frameworks of numeracy's core facets (Table 1). Third, in order to derive subjective meanings, we recognised adults with learning difficulties as experts in acting out numeracy under the conditions of an impairment.

To this end, we combined the principles of participatory research (von Unger 2014; Walmsley and Johnson 2016) with grounded theory methodology (GTM) in the tradition of Strauss and Corbin (1990) and Strübing (2014) (for more detail see Curdt and Schreiber-Barsch, forthcoming). Implementing participatory research principles in the context of disability, particularly that of learning difficulties, has increased in the last two decades (Buchner et al. 2011; Chappell 2000; Di Lorito et al. 2018; Stalker 2014; Porter and Lacey 2005) and has also entered the field of numeracy (Prendergast et al. 2017). Moreover, we saw using GTM as appropriate for a yet-under-researched phenomenon and for our aim of developing a substantive theory (Merriam and Tisdell 2016, pp. 31-33). The iterative process used in data sampling, analysis and theory development, called theoretical sampling (Strauss and Corbin 1990, pp.176-193), aims to achieve the theoretical saturation of the emerging theory (pp. 188, 193). The multilevel analysis follows the concept of coding toward an increasing level of abstraction. This means of generating theory via theoretical sampling pursues not a statistical representation but a conceptual or analytical representation (Strübing 2014, p. 31; Merriam and Tisdell 2016, p. 32).

\subsection{Research design}

In the heuristic framework for our data collection and analysis, we synthesised six core facets of numeracy (Table 1). We generated and concretized the synthesis, according to the principles of GTM, by referring to both the theoretical and conceptual knowledge in the literature as "sensitizing concepts" (Kelle and Kluge 2010, pp. 28-30), and to the evolving data (see Footnote 2). This synthesis was necessary to ensure that we established a common baseline with which to identify the core facets of numeracy, taken, on the one hand, from the classification used by the PIAAC (Zabal et al. 2013) and its predecessors (Gal et al. 2020) and, on the other hand, from the studies that we identified to be relevant 
Table 1 Synthesis of numeracy facets. Source: authors

\begin{tabular}{|c|c|c|c|}
\hline Facet & Subcomponent(s) of facet & & Sources \\
\hline Space and shape & Spatial orientation/experience/concept & (Geographic) positioning/localisation & \\
\hline Numbers and calculating & $\begin{array}{l}\text { Calculating/quantifying the world } \\
\text { with numbers }\end{array}$ & Understanding/sense of numbers & \\
\hline Size and measurements & $\begin{array}{l}\text { Handling units of measurement and } \\
\text { measurement instruments }\end{array}$ & $\begin{array}{l}\text { Adjusting choice of measurement } \\
\text { instrument and the object to be } \\
\text { measured in an appropriate way }\end{array}$ & $\begin{array}{l}\text { Synthesis (Zabal et al. 2013; DVV } \\
\text { 2017; FHH 2011; KMK 2004; } \\
\text { ISB 2003) }\end{array}$ \\
\hline Patterns and structures & Identifying patterns and relations & Regularities and routines & \\
\hline $\begin{array}{l}\text { Probabilities, frequencies } \\
\text { and chances }\end{array}$ & $\begin{array}{l}\text { Identifying probabilities and insecuri- } \\
\text { ties (e.g., frequency distributions in } \\
\text { everyday life) }\end{array}$ & & \\
\hline Artifacts & $\begin{array}{l}\text { Using visual aids (e.g., lists, pictures, } \\
\text { invoices, timetables) }\end{array}$ & $\begin{array}{l}\text { Useful devices/technologies/objects/ } \\
\text { human function holders (e.g., } \\
\text { assistants) }\end{array}$ & \\
\hline
\end{tabular}

for adult basic education and our sample. The latter studies included the following: the current Hamburg primary school mathematics curriculum (FHH 2011), an exemplary primary school mathematics curriculum for students labelled as intellectually disabled (ISB 2003); the national standards in school mathematics (KMK 2004); and the basic adult education curriculum on mathematics (DVV 2017). These works also corresponded to the facets identified by Browder et al. (2008), Prendergast et al. (2017) and Faragher (2019). The synthesis allowed us to find associations between the numeracy-related abilities that we observed in the shadowing of participants and in the interviews, and the agreedupon overall facets of numeracy.

\subsubsection{Sampling}

The sampling of all three phases was guided by our goal of examining numeracy-related activities in all four identified contexts of everyday life. Following the principles of theoretical sampling and conceptual representation, we ensured a balanced distribution of participants across contexts and genders; and we aimed for maximal contrast in terms of living situations and ages. In order to conduct shadowing and interviews, it was necessary that respondents had abilities at their command that allowed them to communicate verbally with us, to move without personal assistance and to be able and willing to explain. In ICF's terms (see Sect. 2.2), this corresponded to individuals qualified as experiencing mild-to-moderate difficulties in capacity and performance qualifiers in the activities and participation component (WHO 2001, pp. 237-239).

This led us to use snowball sampling and to seek respondents at places that were frequently and commonly used by the target persons. Thus, we visited places that were explicitly meant for adults with learning difficulties (such as sheltered workshops, social venues and selfadvocacy groups) and asked to speak to people in these locations (e.g., via presentations of our research project $[n=11])$. Finally, we addressed potential ethical issues by placing particular emphasis on gaining informed consent for our procedures of data collection, analysis and dissemination (Porter and Lacey 2005, p. 92-95; Buchner 2008). By making use of principles of participatory research, we were thus able to gather data from persons who are underrepresented in the extant scholarly body of literature, and difficult to reach using traditional test methods (see Sect. 2). One common worry amongst the participants was that this would 'not be a math test'. Overall, we neither intended a generalisation of our findings nor a classification of the persons in our sample according to their level of functioning or IQ score.

\subsubsection{Shadowing, interviews, focus groups}

We used the shadowing method (Bøe et al. 2017) for our in situ explorations of numeracy practices. Pre-tested $(n=2)$, we carried out 11 shadowings (lasting between 2 and $7.5 \mathrm{~h}$ ). The participants were aged from 18 to 80 (6 male, 4 female, 1 transgender); 6 were living with their parents, 3 were living in supportive housing or assistedliving facilities and 2 were living alone. Regarding their living situations, two received an (invalidity) pension, four were employed at a sheltered job or workshop, four attended vocational schools and 1 was completing an internship. We asked respondents to allow us to shadow them whilst they conducted their daily activities as they usually performed them; thus, they were in full control of the circumstances of the shadowing. We agreed upon a meeting point, and from that point, a researcher followed 
the participants wherever they went. The researcher used a recording template ${ }^{2}$ (observational protocol) throughout the shadowing.

After completing the shadowing, we conducted semistructured interviews $(n=13)$ (lasting from $30 \mathrm{~min}$ to $2.5 \mathrm{~h}$ ). For our interview method, we combined principles from problem-oriented interviews (Witzel 2000) and qualitative interview methodology for adults with learning difficulties (Buchner 2008). Due to our use of snowball sampling and to individual preferences, there was only a small overlap $(n=3)$ between the shadowing participants and the interview sample. The adults who were interviewed were aged 18-42 ( 7 male, 6 female). Four of them lived with parents, 5 alone (one together with a spouse, one with a daughter) and 4 in supportive housing or assisted living facilities. The majority (7 people) were employed at a sheltered job or workplace, 3 at a school and 3 were completing an internship.

The third phase of the research design (09/2019-01/2020) represented yet another shift in perspective in that we conducted focus groups (Barbour 2007) with professionals. However, as our data collection for this third phase has not yet been finalised, the following section focuses only on the first two steps.

\subsection{Selected insights into the data}

In the iterative analysis so far, three intertwined categories have been identified as contributing to a response to the research questions, and thus eventually to generating a grounded theory: social embeddedness (societal or institutional context), subjective meaning (being ascribed to numeracy-related activities) and social interaction (verbal or non-verbal social interaction with particular persons while performing numeracy-related activities). These categories are illustrated below by three examples. (All of the participants' names have been anonymised; capital letters highlight an emphasis by the respondent.)

\subsubsection{Shadowing sequence: teaching housekeeping at a vocational school}

In a lesson on housekeeping, the teacher explained that folding napkins has been one of the recent tasks that the students have undertaken in accordance with the curriculum:
Teacher (in a derogatory tone): "It [folding napkins] was surprisingly difficult for all of them".

The teacher stopped in his statement and asked the researcher: "Is folding napkins part of everyday mathematics?"

The researcher confirmed this, while the shadowee, standing close beside both of them, added, "If you need to fold at right angles to each other, you need to know what this is" (SH_7, para 9, no. 13-14, authors' translation).

Whereas the teacher dismissively labelled the shadowee as belonging to a group that has very limited skills in everyday mathematics due to their level of intellectual functioning, the shadowee actually refuted this via a verbal social interaction. In doing this, the shadowee demonstrated abilities in spatial orientation (axial symmetry), used the correct term for the unit of measurement ('right angles') and explained why folding napkins was a numeracy-related activity. The sequence showcased the social embeddedness in an institutional context of teaching school mathematics in a formal learning setting and assessing skills according to standards set by a curriculum.

\subsubsection{Interview sequence: recounting the mastery of calculating}

The non-intentional but successful transfer between formal and informal learning settings in the wake of numeracy learning became evident in an interview with a participant:

Well, regarding calculating, IN THE PAST at school I came in dead last. It was then quite funny in the vocational school, there, I was always the fastest one ... funny enough. We always did corner-calculating ${ }^{3}$ IN THE MORNINGS for the start of the day. ... At the beginning, I was always the last one. Towards the end of the school year, I was the fastest one. And then all my classmates asked: how do you do that? How do you get the result that quickly? Yes, I said, I play computer games. They said: you are winding us up. No, I have, there is a GAME that is called [game], a bus simulator. And it is so realistic that you can even sell TICKETS. And it does not show how much change to make, but you have to calculate it. So, you have a maximum of $10 \mathrm{~s}$ or $5 \mathrm{~s}$, then the other passengers start to grumble: Where is my change? You have given me

\footnotetext{
${ }^{2}$ Based on the categories that ISB-Staatsinstitut für Schulqualität und Bildungsforschung München (2003) and Zabal et al. (2013) identified, the template included a vertical roster (listing place, situation, event) and a horizontal line (listing space/orientation, time, order [sorting, comparing], numbers and digits, quantity, social interaction/ contacts, artifacts (objects) and comments).
}

\footnotetext{
3 This is a typical German game in school mathematics lessons: All of the students stand in one corner of the classroom, and an arithmetical task is posed. The first one to respond with the correct answer is allowed to proceed to the next corner; the winner is the one who reaches the corner of departure the fastest.
} 
TOO MUCH change. You have given me TOO LITTLE change. That means you have to calculate all that (I_3_\#84-88\#, authors' translation).

The numeracy events reported here referred to formal and informal learning. The numeracy demand (do mental arithmetic under time pressure) was the same in both cases, but the mastery was achieved during free time and the acquired skill was then transferred. Moreover, the sequence reflected the interviewee's abilities to master size and measurements (e.g., dealing with time as a unit of measurement), numbers (calculations) as well as patterns and structures (relation between time and coping with a task). The numeracy practice perspective unfolded via the social embeddedness of this numeracy-related learning in the institutional context of a school that uses classification procedures according to intellectual functioning and corresponding abilities (better-worse). The subjective meaning arose in the interviewee's personal interest that-unintentionally-resulted in the development of numeracy learning.

\subsubsection{Interview sequence: recounting the mastery of being punctual to work}

The interviewee described a daily routine that he developed as a niche strategy for being punctual to work:

I've got several ... several alarm clocks, I've got ... After some time, the same trick doesnot WORK anymore. For example, I never have the precise wake-up time on my alarm clock. Sometimes I set the time half an hour EARLIER, actually always, up to 40 or $50 \mathrm{~min}$ earlier than the correct time. So that I cannot REMEMBER. So that I ... when I take a look at the clock, that I never EXACTLY know what the correct time is. So that I outsmart myself, then comes the impulse: so, now get up! ... But it does not work all the time.... So that the signal comes: Oh, now it is time. ... So, as I said, it does not work forever, then I have to reset the time again. And that, I'll do randomly (I_10_\#46-54\#, authors' translation).

The alarm clock served as an artifact. The participant's use of the clock represented his ability to adjust an object to be measured (time, wake-up time) by means of an appropriate measuring instrument (alarm clock). The interviewee reported adjusting the time of the alarm clock in an incorrect manner. By doing this, he sought consciously to produce uncertainty; however, this practice generated security through creating a routine. This routine ensured the regularity of causing uncertainty regarding the correct time each morning, resulting in a pattern of re-/adjusting the alarm clock every evening. Moreover, in terms of handling units of measurement (time), the interviewee chose a temporal range of 40-50 min. This indicated his understanding of numbers and his playful usage of them - the range was wide enough to generate the routine but was not so wide as to negate the goal of punctuality. This practice also proved the interviewee's ability to identify probabilities (random choice). The reason for developing this niche strategy, however, only derived from another section of the interview, in which he reported on social embeddedness (social norm of punctuality) and subjective meaning: The interviewee explained that he was once dismissed from a job for being late, causing him to suffer from social isolation.

\section{Discussion}

We support the view that the key to understanding numeracy practices is to recognise their context contingency, social embeddedness and subjective meaning (see Evans et al. 2017). If we were unaware of the biographical background, it would hardly be possible for us to identify why this participant developed this niche proficiency of being punctual to work. Throughout the data, the social norm of punctuality, which is of high value in the German cultural context, became prevalent; many routines developed by the sample corresponded to this norm. For many participants this meant habitually planning time schedules, and traveling on public transport from 30 min up to an hour earlier than the agreedupon time. In some of our focus groups with professionals, there was some labelling of these practices as awkward and reflective of low intellectual functioning; however, from a resource-oriented perspective, we recognise the appropriate and purposeful function of such actions in ensuring participation.

Likewise, a social practice perspective renders visible "ability conflicts" (Weisser 2018). This aspect was shown above in the sequence of folding napkins, but it was also seen in the research process itself. There, in another interview, the researcher asked for an example of how the respondent spent his free time:

Respondent: 'Well, free time, I like to take the subway.' Researcher: 'Okay.'

Respondent: 'Yes [pause].'

Researcher: 'And how ... How do you do that ... So, where do you go to, or ...?'

Respondent: 'Driving back and forth.'

Researcher: 'Driving back and forth?'

Respondent: 'Yes, just like that.'

The respondent then described which subway to take to what destination and how to orientate with only very limited reading skills; he then answered the question concerning how he decides where to go: 
Respondent: 'That I decide by myself. I myself' (I_4_\#83-96\#, authors' translation).

The above example demonstrates the value of a qualitative approach when seeking information about the subjective meaning of numeracy-related activities; for the researcher, such meaning might only make sense at second glance. This response thus showcases a clash between the interviewer's expectations (regarding possible ways to spend free time) and the respondent's choice and interest, which are most likely influenced by his living in the restricted setting of an assisted living facility. The purpose of the practice is neither reaching a certain destination nor the act of taking the subway itself; rather, this practice is a way for him to be as independent and self-determined as possible-one which is enabled by his mastery of numeracy-related abilities (i.e., spatial orientation). Hence, a social practice perspective reveals abilities beyond common assumptions of who is an abled person and what is a skilful practice (Williams et al. 2018 , p. 170). In this sense, practices are not value- or context-free, but rather inherently political (Jackson et al. 2018).

\section{Conclusion}

In this paper we aimed to elaborate on numeracy practices of adults with learning difficulties; yet, our research approach has also limitations. Echoing Di Lorito et al. (2018) we must note that a small recruited sample of adults with learning difficulties-and particularly those with abilities which allow them to respond to the research's requirements (see Sect. 3.1.1)-might be unrepresentative of the general population. We did not intend to imply statistical generalisation or representativeness with this research. However, our focus on social practices as the unit of analysis and our use of research methodologies and methods proved appropriate for calling attention to abilities, meanings and events that have thus far been unrecognised in existing research. In this respect, participatory-oriented bottom-up approaches and in situ methods such as shadowing can work to enhance the representativeness of extant knowledge regarding the numeracy of adults.

Another limitation has to do with the dilemma of labelling. We accept that our use of the label 'adults with learning difficulties' does not eliminate the risk of (re)producing stigma and deficit-driven approaches. This usage also does not offer a solution to the problems of the diversity of disability's policy conceptualisations or the imperfect process of aggregating individuals into a single social group (Tan et al. 2019, p. 1). Nonetheless, in our view, this situation rather calls for further research on exposing these dilemmas by reflecting and debating on definitional issues and epistemological foundations and their impact on scholarly work as well as on individual lives.

Therefore, we recommend that studies should seek to include the voices of adults with learning difficulties. This inclusion would form the basis for a more resource-oriented perspective in the debate on numeracy, and it would position these individuals as "competent and capable of engaging in mathematics" (Jackson et al. 2018, p. 243; see also Tan et al. 2019, p. 1; Sect. 2.1). We predict that this change would result in further development of mathematics curricula that focus on "real-life situations" (Prendergast et al. 2017, p. 171), that value a more subjective lens for what serves as a reason for learning, and that prioritise the functionality of personal learning strategies and learning material. In Germany, these focuses are not yet satisfactorily covered within the mathematics curriculum for adults (DVV 2017), which is informed instead by a deficit-oriented perspective on fixing "biographies of failure" (see Sect. 2.1).

We conclude by emphasising the emancipatory potential of acting out numeracy, particularly under the conditions of an impairment. As indicated by the insights derived from our data, acting out numeracy clearly enables adults with learning difficulties to lead their lives as independently, actively and self-determinately as is possible and desirable. Becoming and being numerate through learning thus promises to empower individuals to make informed decisions to take part in society and community, thereby transforming the world they live in (Craig 2018, p. 63). Yet, abilities are an individual's reservoir; they may also be incorporating a potential that is only partially realised (see Sect. 2.3). Leading a life as independently and actively as possible thus depends not only on the opportunities and enabling conditions of an individual's context and environment, but also on the individual's desires, interests and "willingness to do the mathematics" (Faragher 2019, p. 208). Adult education has an essential role to play in contributing to the realisation of a "numerate adult citizenship" (p. 206; Niss 1994, p. 376). This role necessitates enabling conditions and opportunities that help learners make informed decisions (ability), nourish their interest and motivation to decide (desire), and recognise them as abled decision-makers in society (recognition).

Acknowledgements Open Access funding provided by Projekt DEAL.

Open Access This article is licensed under a Creative Commons Attribution 4.0 International License, which permits use, sharing, adaptation, distribution and reproduction in any medium or format, as long as you give appropriate credit to the original author(s) and the source, provide a link to the Creative Commons licence, and indicate if changes were made. The images or other third party material in this article are included in the article's Creative Commons licence, unless indicated otherwise in a credit line to the material. If material is not included in the article's Creative Commons licence and your intended use is not permitted by statutory regulation or exceeds the permitted use, you will 
need to obtain permission directly from the copyright holder. To view a copy of this licence, visit http://creativecommons.org/licenses/by/4.0/.

\section{References}

AAIDD-American Association on Intellectual and Developmental Disabilities (2019). Definition of intellectual disability. https:// www.aaidd.org/intellectual-disability/definition. Accessed 28 Nov 2019.

Barbour, R. (2007). Doing focus groups. Los Angeles: SAGE.

Barnes, C. (2014). Understanding the social model of disability. Past, present and future. In N. Watson, A. Roulstone, \& S. Thomas (Eds.), Routledge handbook of disability studies (pp. 12-29). New York: Routledge.

BMAS - Bundesministerium für Arbeit und Soziales. (2016). Zweiter Teilhabebericht der Bundesregierung über die Lebenslagen von Menschen mit Beeinträchtigungen. https://www.bmas.de/Share dDocs/Downloads/DE/PDF-Publikationen/a125-16-teilhabebe richt.pdf;jsessionid $=29$ CAB83561B784C4FBAA1F908D7887 $60 ? \quad$ blob $=$ publicationFile \& v =9. Accessed $01 \mathrm{Jul} 2019$.

Bøe, M., Hognestad, K., \& Waniganayake, M. (2017). Qualitative shadowing as a research methodology for exploring early childhood leadership in practice. Educational Management Administration and Leadership, 45(4), 605-620.

Browder, D. M., Spooner, F., Ahlgrim-Delzeel, L., Harris, A. A., \& Wakeman, S. (2008). A meta-analysis on teaching mathematics to students with significant cognitive disabilities. Exceptional Children, 74(4), 407-432. https://doi.org/10.1177/0014402908 07400401 .

Buchner, T. (2008). Das qualitative Interview mit Menschen mit so genannter geistiger Behinderung-Ethische, methodologische und praktische Aspekte. In G. Biewer, M. Luciak, \& M. Schwinge (Eds.), Begegnung und Differenz: Menschen—Länder-Kulturen (pp. 516-528). Klinkhardt, Bad Heilbrunn: Beiträge zur Heil- und Sonderpädagogik.

Buchner, T., Koenig, O., \& Schuppener, S. (2011). Gemeinsames Forschen mit Menschen mit intellektueller Behinderung: Geschichte, Status quo und Möglichkeiten im Kontext der UN-Behindertenkonvention. Teilhabe, 50(1), 4-10.

Burghardt, D., Dederich, M., Dziabel, N., Höhne, T., Lohwasser, D., Stöhr, R., et al. (2017). Vulnerabilität. Pädagogische Herausforderungen. Stuttgart: Kohlhammer Verlag.

Campbell, F. K. (2009). Contours of ableism. New York: Palgrave Macmillan.

Chapman, R. (2013). An exploration of the self-advocacy support role through collaborative research: 'There should never be a them and us'. Journal of Applied Research in Intellectual Disabilities, $27,44-53$.

Chappell, A. L. (2000). Emergence of participatory methodology in learning difficulty research: Understanding the context. British Institute of Learning Disabilities. British Journal of Learning Disabilities, 28, 38-43. https://doi.org/10.104 6/j.1468-3156.2000.00004.x.

Craig, J. (2018). The promises of numeracy. Educational Studies in Mathematics, 99(1), 57-71. https://doi.org/10.1007/s1064 9-018-9824-5.

Creswell, J. W. (2003). Research design. Qualitative, quantitative, and mixed methods approaches (2nd ed.). Thousand Oaks: SAGE.

Curdt, W., \& Schreiber-Barsch, S. (forthcoming). Abilities in the blind spot of testing regimes: Eliciting the benefits and limitations of participatory research approaches on numeracy in adult basic education. International Review of Education.
Di Lorito, C., Bosco, A., Birt, L., \& Hassiotis, A. (2018). Co-researching with adults with intellectual disability: A systematic review. Journal of Applied Research in Intellectual Disabilities, 31(5), 669-686. https://doi.org/10.1111/jar.12435.

DVV-Deutscher Volkshochschulverband. (2017). Rechnen. DVVRahmencurriculum (2nd Ed.). Bonn: DVV. https://www.volks hochschule.de/microsite/grundbildung/unterrichten/Curricula. php. Accessed 15 May 2019.

Edgerton, R. B. (1967). The cloak of competence: Stigma in the lives of the mentally retarded. Berkeley: University of California Press.

Evans, J. (2019). Adult skills surveys and transnational organisations: Globalising educational policy. In J. Evans, S. Ruane, \& H. Southall (Eds.), Data in society: Challenging statistics in an age of globalisation (pp. 65-77). Bristol: Policy Press.

Evans, J., Yasukawa, K., Mallows, D., \& Creese, B. (2017). Numeracy skills and the numerate environment: Affordances, opportunities, supports and demands. Adults Learning Mathematics, 12(1), $17-26$.

Faragher, R. (2019). The new 'functional mathematics' for learners with down syndrome: Numeracy for a digital world. International Journal of Disability, Development and Education, 66(2), 206-217. https://doi.org/10.1080/1034912X.2019.1571172.

FHH-Freie und Hansestadt Hamburg, Behörde für Schule und Berufsbildung (2011). Bildungsplan Grundschule. Mathematik. Hamburg. https://www.hamburg.de/contentblob/2481796/ e71dafe076bf597d320c6a76ae57263c/data/mathematik-gs.pdf. Accessed 18 Jul 2019.

Fritz, A., Haase, V. G., \& Räsänen, P. (2019). International handbook of mathematical learning difficulties: From laboratory to the classroom. Cham: Springer. https://doi.org/10.1007/978-3319-97148-3.

Gal, I. (2000). The numeracy challenge. In I. Gal (Ed.), Adult numeracy development: Theory, research, practice (pp. 9-31). Cresskill: Hampton Press.

Gal, I., Alatorre, S., Close, S., Evans, J., Johansen, L., Maguire, T., Manly, M. \& Tout, D., PIAAC Numeracy Expert Group (2009). PIAAC numeracy: A conceptual framework. OECD Education Working Paper No. 35. https://doi.org/10.1787/220337421165.

Gal, I., Grotlüschen, A., Tout, D., \& Kaiser, G. (2020). Numeracy, adult education, and 'vulnerable' learners: A critical review of a neglected field. ZDM Mathematics Education, 52, 2. (this issue).

Geiger, V., Goose, M., \& Forgasz, H. (2015). A rich interpretation of numeracy for the 21st century: A survey of the state of the field. ZDM Mathematics Education, 47(4), 531-548. https://doi. org/10.1007/s11858-015-0708-1.

GESIS (2012). PIAAC Deutschland 2012-Hintergrundfragebogen. GESIS Leibnitz-Institut für Sozialwissenschaften. https://www. gesis.org/fileadmin/piaac/Downloadbereich/PIAAC_BQ_Final _deutsch.pdf. Accessed 01 Jul 2019.

Goodley, D. (2017). Disability studies. An interdisciplinary introduction (2nd ed.). Los Angeles: Sage.

Higgins, A. (2014). Intellectual disability or learning disability? Let's talk some more. Research and Practice in Intellectual and Developmental Disabilities, 2, 142-147.

ISB - Staatsinstitut für Schulqualität und Bildungsforschung München (2003). Lehrpläne Förderschwerpunkt Geistige EntwicklungGrund- und Hauptschulstufe. Mathematik. https://www.isb.bayer n.de/download/9014/mathematik.pdf. Accessed 01 Jul 2019.

Jackson, K. (2018). Numeracy and power: Facilitating learning of numeracy as asocial practice. In K. Yasukawa, A. Rogers, K. Jackson, \& B. V. Street (Eds.), Numeracy as social practice. Global and local perspectives (pp. 169-170). London: Routledge.

Jackson, K., Rogers, A., \& Yasukawa, K. (2018). Expanding and deepening the terrain: Numeracy as social practice. In K. Yasukawa, A. Rogers, K. Jackson, \& B. V. Street (Eds.), Numeracy as social 
practice: Global and local perspectives (pp. 243-254). London: Routledge.

Kelle, U., \& Kluge, S. (2010). Vom Einzelfall zum Typus (2nd ed.). Wiesbaden: VS Verlag.

KMK-Konferenz der Kultusminister der Länder in der Bundesrepublik Deutschland (2004). Bildungsstandards im Fach Mathematik für den Primarbereich. Beschluss vom 15.10.2004. Luchterhand. https://www.kmk.org/fileadmin/veroeffentlichungen_beschluess e/2004/2004_10_15-Bildungsstandards-Mathe-Primar.pdf. Accessed $01 \mathrm{Jul} 2019$.

Magne, O. (2003). Literature on special educational needs in mathematics: A bibliography with some comments. (4th Ed.). Educational and Psychological Interactions, 124. Malmö, Sweden: School of Education. http://citeseerx.ist.psu.edu/viewdoc/downl oad?doi=10.1.1.463.5013\&rep=rep1\&type $=$ pdf. Accessed 04 Dec 2019.

Merriam, S. B., \& Tisdell, E. J. (2016). Qualitative research. A guide to design and implementation (4th ed.). San Francisco: Jossey-Bass.

Meyerhöfer, W. (2017). Einführung. In DVV—Deutscher Volkshochschulverband. Rechnen. DVV-Rahmencurriculum (pp. 3-5). (2nd Ed.). Bonn: DVV. https://www.volkshochschule.de/microsite/ grundbildung/unterrichten/Curricula.php. Accessed 05 May 2019.

Neuhäuser, G., \& Steinhausen, H.-C. (2013). Epidemiologie, Risikofaktoren und Prävention. In G. Neuhäuser, H.-C. Steinhausen, F. Hässler, \& K. Sarimski (Eds.), Geistige Behinderung: Grundlagen, erscheinungsformen und klinische probleme, behandlung, rehabilitation und rechtliche aspekte (pp. 15-29). Stuttgart: Kohlhammer.

Niss, M. (1994). Mathematics in society. In R. Biehler, R. W. Scholz, R. Sträßer, \& B. Winkelmann (Eds.), Didactics of mathematics as a scientific discipline (pp. 367-378). Dordrecht: Kluwer Academic Publishers.

OECD_Organization for Economic Cooperation and Development (2016). The survey of adult skills. Reader's companion, Second Ed. Paris: OECD Publishing. http://dx.doi.org/10.1787/97892 64258075-en. Accessed 28 Nov 2019.

Patterson, M. B., \& Paulson U. G. (2015). Adult transitions to learning in the USA: What do PIAAC survey results tell us? Commissioned by American Institutes for Research. https://static1.squar espace.com/static/51bb74b8e4b0139570ddf020/t/54da7639e4 b0990535ec333a/1423603257773/Patterson_Paulson_PIAAC .pdf. Accessed 17 Jan 2019.

Peng, P., Wang, C., \& Namkung, J. (2018). Understanding the cognitive related to mathematics difficulties: A meta-analysis on the cognitive deficit profiles and the bottleneck theory. Review of Educational Research, 88(3), 434-476. https://doi.org/10.3102/00346 54317753350.

Porter, J., \& Lacey, P. (2005). Researching learning difficulties. A guide for practitioners. London: Paul Chapman Publishing.

Prendergast, M., Spassiani, N. A., \& Roche, J. (2017). Developing a mathematics module for students with intellectual disability in higher education. International Journal of Higher Education, 6(3), 169-177. https://doi.org/10.5430/ijhe.v6n3p169.

Reckwitz, A. (2003). Grundelemente einer theorie sozialer praktiken: eine sozialtheoretische perspektive. ZfS Zeitschrift für Soziologie, 32(4), 282-301.

Scherer, P., Beswick, K., DeBlois, L., Healy, L., \& Opitz, E. M. (2016). Assistance of students with mathematical learning difficulties: How can research support practice? ZDM Mathematics Education, 48, 633-649. https://doi.org/10.1007/s11858-016-0800-1.

Spassiani, N. A., \& Friedman, C. (2014). Stigma: Barriers to culture, identity, and inclusion for people with intellectual and developmental disabilities. Inclusion, 2, 329-341. https://doi. org/10.1352/2326-6988-2.4.329.

Stalker, K. (2014). Theorizing the position of people with learning difficulties within disability studies. Progress and pitfalls. In N.
Watson, A. Roulstone, \& C. Thomas (Eds.), Routledge handbook of disability studies (pp. 122-135). New York: Routledge.

Stepanek-Lockhart, A. (2018). Monitoring ESD: Lessons learned and ways forward. In UNESCO (Ed.), Issues and trends in education for sustainable development (pp. 215-231). Paris: UNESCO.

Straka, G. A., \& Macke, G. (2009). Berufliche Kompetenz: Handeln können, wollen und dürfen. $B W P, 3,14-17$.

Strauss, A., \& Corbin, J. (1990). Basics of qualitative research. Grounded theory procedures and techniques. California: Sage.

Street, B. (1984). Literacy in theory and practice. Cambridge: Cambridge University Press.

Street, B., Baker, D., \& Tomlin, A. (2008). Navigating numeracies. Home/school numeracy practices. Dordrecht: Springer.

Strübing, J. (2014). Grounded theory: Zur sozialtheoretischen und epistemologischen Fundierung eines pragmatistischen Forschungsstils. Wiesbaden: Springer VS.

Tan, P., Lambert, R., Padilla, A., \& Wieman, R. (2019). A disability studies in mathematics education review of intellectual disabilities: Directions for future inquiry and practice. Journal of Mathematical Behavior. https://doi.org/10.1016/j.jmathb.2018.09.001.

UN-United Nations (2006). Convention on the rights of persons with disabilities. http://www.un.org/disabilities/documents/convention /convention_accessible_pdf.pdf. Accessed 01 Jul 2019.

UN-United Nations (2015). United Nations (2015): International Day of Persons with Disabilities, 3 December 2015. https://www. un.org/development/desa/disabilities/international-day-of-perso ns-with-disabilities-3-december/international-day-of-personswith-disabilities-3-december-2015.html\#background. Accessed $09 \mathrm{Jul} 2019$.

Vogel, S. A., \& Reder, S. (1998). Learning disabilities, literacy, and adult education. Baltimore: Brookes.

von Unger, H. (2014). Partizipative Forschung. Einführung in die Forschungspraxis. Wiesbaden: Springer VS.

Waldschmidt, A. (2019). Handbuch disability studies. Wiesbaden: Springer VS.

Walmsley, J., \& Johnson, K. (2016). Vorwort. In T. Buchner, O. Koenig, \& S. Schuppener (Eds.), Inklusive forschung. gemeinsam mit menschen mit lernschwierigkeiten forschen (pp. 9-12). Bad Heilbrunn: Verlag Julius Klinkhardt.

Watson, N., Roulstone, A., \& Thomas, C. (2014). Routledge handbook of disability studies. New York: Routledge.

Weisser, J. (2018). Inklusion, fähigkeiten und disability studies. In T. Sturm \& M. Wagner-Willi (Eds.), Handbuch schulische inklusion (pp. 93-106). Opladen, Toronto: Barbara Budrich.

WHO-World Health Organization. (2001). International classification of impairments, activities and participation. Geneva: WHO.

WHO_World Health Organization. (2007). Atlas: Global resources for persons with intellectual disabilities. Geneva: WHO.

Wiliams, V., Tarleton, B., Heslop, P., Porter, S., Sass, B., Blue, S., et al. (2018). Understanding disabling barriers: A fruitful partnership between disability studies and social practices? Disability and Society, 33(2), 157-174.

Witzel, A. (2000). Das problemzentrierte Interview. Forum Qualitative Sozialforschung/Forum: Qualitative Social Research 1(1), Art. 22. https://doi.org/10.17169/fqs-1.1.1132. http://www.qualitativ e-research.net/index.php/fqs/article/view/1132/2520. Accessed 19 Jan 2019

Yasukawa, K., Jackson, K., Kane, P., \& Coben, D. (2018a). Mapping the terrain of social practice perspectives of numeracy. In K. Yasukawa, A. Rogers, K. Jackson, \& B. Street (Eds.), Numeracy as social practic: Global and local perspectives (pp. 3-17). London, New York: Routledge.

Yasukawa, K., Rogers, A., Jackson, K., \& Street, B. (2018b). Numeracy as social practice. Global and local perspectives. London, New York: Routledge. 
Zabal, A., Martin, S., Kaukein, A., Rammstedt, B., Baumert, J., \& Klieme, E. (2013). Grundlegende Kompetenzen der erwachsenen Bevölkerung in Deutschland im internationalen Vergleich. In B. Rammstedt (Ed.), Grundlegende Kompetenzen Erwachsener im internationalen Vergleich: Ergebnisse von PIAAC 2012 (pp. 31-76). Münster: Waxmann.

Zirfas, J. (2017). Vulnerabilität. Ein pädagogisch-anthropologischer Zugang zur Verantwortung. In S. Vock \& R. Wartmann (Eds.),
Verantwortung: Im Anschluss an poststrukturalistische Einschnitte (pp. 171-185). Paderborn: Ferdinand-Schöningh.

Publisher's Note Springer Nature remains neutral with regard to jurisdictional claims in published maps and institutional affiliations. 